Ekonomia - Wroclaw Economic Review 23/3 (2017)

Acta Universitatis Wratislaviensis

No 3807

DOI: 10.19195/2084-4093.23.3.8

Monika Raulinajtys-Grzybek

Szkoła Główna Handlowa w Warszawie

Katedra Rachunkowości Menedżerskiej

mrauli@sgh.waw.pl Instytut Misesa

\title{
Krzysztof Frydziński
}

Prezes Zarządu FiM Consulting Sp. z o.o.

Politechnika Warszawska

Instytut Transportu

krzysztof.frydzinski@fim.pl

\section{Uproszczony model wdrożenia rachunku kosztów działań sterowany czasem, bazujący na podejściu dwuetapowym}

Artykuł nadesłany: 4 września 2017 r.; artykuł zaakceptowany: 14 października 2017 r.

JEL Classification: M41, M11

Keywords: time-driven activity-based costing, cost accounting implementation, process cost analysis

Abstract

A simplified model for the implementation of a Time-Driven Activity Based Cost Accounting (TD $A B C$ ) approach, consisting of two stages

The article presents a suggested approach to implementing the Time-Driven Activity Based Cost Accounting (TD ABC), consisting of two stages. The first step - intermediate in relation to full implementation - is to determine the costs of activities and processes. This approach allows for process management in accordance with the horizontal axis of the CAM-I model and, as proven by the conducted empirical research, it can be implemented within 4 man-days of the implementation team's work. The most important benefit of dividing the implementation into two steps is that the company gets the information that is useful for management - on the costs of processes, the process assessment measures, and the costs of untapped potential. In view of the previous research linking the success of the $\mathrm{ABC}$ implementation with managerial support, it can be assumed that the adoption of a two-step implementation approach will have a positive impact on the dissemination of the TD ABC model. 


\section{Wstęp}

Koncepcja rachunku kosztów działań (ang. activity-based costing, ABC) powstała wskutek wzrostu świadomości ograniczeń związanych z tradycyjnymi rachunkami kosztów, czyli modelami zakładającymi, że głównym czynnikiem zmienności kosztów są rozmiary działalności przedsiębiorstwa (por. np. Cooper, Kaplan 1988, s. 20-27). Tradycyjne rozwiązania rachunku kosztów nie obejmują swym zakresem wielu problemów, przed którymi stają przedsiębiorstwa, takich jak wzrost udziału kosztów pośrednich działalności, realizacja działań niezależnych od rozmiarów produkcji czy problem niewykorzystanego potencjału (Świderska 2010; Rybarczyk 1998, 2000). Pomiar i kontrola kosztów w przekroju jednostek organizacyjnych (miejsc powstawania kosztów) oraz produktów — typowa dla tradycyjnego rachunku kosztów - nie sprawdza się zwłaszcza w przedsiębiorstwach, w których dominuje procesowe podejście do zarządzania.

Rozwój rachunku kosztów działań doprowadził do wypracowania jego kolejnych modyfikacji, mających usprawnić proces podejmowania decyzji, planowania i kontroli. Można by oczekiwać, że mechanizm wypracowany prawie 30 lat temu stanie się jednym z najpowszechniejszych narzędzi rachunkowości zarządczej. W praktyce jednak doświadczenia wskazują na ograniczony poziom wdrożenia modelu. Zastrzeżenia do tradycyjnego modelu ABC mieli sami autorzy, wskazujący, że jego zbudowanie i wdrożenie jest drogie, model jest skomplikowany w utrzymaniu i trudny do modyfikacji. Jako alternatywę zaproponowali model rachunku kosztów działań sterowany czasem (ang. time-driven activity-based costing, TD ABC) (Kaplan, Anderson 2008).

Kalkulacja zgodna z podejściem rachunku kosztów działań (zarówno klasycznego, jak i sterowanego czasem) zakłada konieczność przeprowadzenia dwóch etapów: (1) kalkulacji kosztów działań (całkowitych i jednostkowych) oraz (2) kalkulacji kosztów obiektów finalnych, przede wszystkim produktów lub klientów. Jak wynika z doświadczeń empirycznych, całość procesu wdrożenia może trwać kilka miesięcy, a w przedsiębiorstwach o szerokim portfelu produktów i klientów przeprowadzenie drugiego etapu jest znacznie bardziej czaso- i zasobochłonne niż w wypadku etapu pierwszego.

Celem badania była weryfikacja, czy wdrożenie ABC w kształcie umożliwiającym przeprowadzenie wyłącznie pierwszego etapu kalkulacji pozwala na otrzymanie informacji użytecznych dla zarządzających, przy zaangażowaniu znacznie niższych zasobów niż wymagałoby tego pełne wdrożenie. W artykule przedstawiono metodykę procesu wdrożenia TD ABC, która została zweryfikowana w wyniku wdrożeń w kolejnych przedsiębiorstwach, a także wskazano, jaki zakres informacji uzyskano w badanych przedsiębiorstwach, w których wdrożony model umożliwiał przeprowadzenie tylko pierwszego etapu kalkulacji, to jest ustalenia całkowitych i jednostkowych kosztów działań. 


\section{Istota rachunku kosztów działań i rachunku kosztów działań sterowanego czasem}

Model rachunku kosztów działań w pierwotnej wersji został opisany pod koniec lat osiemdziesiątych XX wieku. Najbardziej znana publikacja w tym zakresie to książka autorstwa Roberta S. Kaplana i Robina Coopera (Kaplan, Cooper 1998), którzy opisują rachunek kosztów działań poprzez pryzmat pytań, na które daje on odpowiedź:

- Jakie działania są wykonywane przez zasoby?

— Ile kosztuje wykonywanie działań i procesów?

— Jakie są przyczyny realizacji działań i procesów?

— Ile działań jest niezbędne do otrzymania efektów — wytworzenia produktów, obsługi klientów?

Kompletny model rachunku kosztów działań przyporządkowuje koszty do działań na podstawie zużycia zasobów w poszczególnych działaniach, przyporządkowuje też koszty do obiektów kosztów na podstawie nośników kosztów działań, czyli informacji o zaangażowaniu danych działań w ich wytworzenie. Dobór nośnika zależy od rodzaju działania. W hierarchii działań wyróżnia się działania na poziomie produktu lub klienta, partii, asortymentu oraz przedsiębiorstwa (Cooper 1990).

Współcześnie najbardziej zaawansowane koncepcje to modele rachunku kosztów działań trzeciej generacji. Pierwsza generacja rachunków kosztów działań identyfikowała wyłącznie działania bezpośrednio związane z produkcją. Druga dostarczała informacji również o kosztach procesów sprzedaży produktów i zarządzania przedsiębiorstwem. Trzecia generacja pozwala zarządzającym dowiedzieć się, jaką wartość dodaną generuje całe przedsiębiorstwo (Nowak 2004, s. 169-170).

Możliwości wykorzystania rachunku kosztów działań zależą od zakresu wdrożenia oraz szczegółowych parametrów modelu, jaki zostanie zaimplementowany w przedsiębiorstwie. Może on być użyteczny w następujących obszarach decyzyjnych: efektywne kształtowanie portfela produktów i klientów, zarządzanie niewykorzystanym potencjałem, reengineering procesów, kontrola operacyjna (Innes, Mitchell 1995, s. 138-140; Świderska, Warowny 2007).

Z systematycznego przeglądu badań dotyczących zastosowania rachunku kosztów działań przeprowadzonego przez Tomasza Wnuka-Pela wynika, że w rzadko których badaniach odsetek firm wykorzystujących to rozwiązanie przekraczał 50\% (Wnuk-Pel 2011, s. 140-142). Analiza wyników badań przeprowadzonych w Polsce jest zdecydowanie mniej optymistyczna — spośród 13 polskich publikacji jedynie w 5 odsetek firm stosujących ABC jest wyższy od 0 , a jedynie w 2 przypadkach ma wartości przekraczające 3\% (odpowiednio 10\% spośród 90 przedsiębiorstw oraz $100 \%$ w badaniu przeprowadzonym na małej próbie 6 przedsiębiorstw) (Wnuk-Pel 2011, s. 180). 
Do podstawowych zarzutów w odniesieniu do $\mathrm{ABC}$ należy względna trudność $\mathrm{w}$ dostarczaniu informacji (w porównaniu z tradycyjnym modelem rachunku kosztów) oraz brak ułatwienia realizacji zadań związanych z pracą (McGowan 1998). Szanse na efektywne wdrożenie zwiększały natomiast różnorodne czynniki, z których najczęściej wskazywanym jest wsparcie kadry zarządzającej i związek z oceną wyników (Shields 1995; McGowan, Klammer 1997; Innes, Mitchell 1995; Innes, Mitchell, Sinclair 2000; Cotton, Jackman, Brown 2003).

Alternatywą dla tradycyjnego modelu $\mathrm{ABC}$ jest rachunek kosztów działań sterowany czasem (ang. time-driven activity-based costing, TD ABC), który wymaga przeprowadzenia dwóch grup czynności:

1. określenia kosztu jednostkowego dostępności poszczególnych działań czyli kosztu wszystkich zasobów zaangażowanych w realizację danego działania w przeliczeniu na jednostkę czasu;

2. ustalenia czasu realizacji danego działania na rzecz poszczególnych obiektów finalnych — produktów lub klientów.

Koncepcja TD ABC wydaje się właściwym kierunkiem w szczególności w odniesieniu do tych przedsiębiorstw lub obszarów, w których realizowane są działania o dużej homogeniczności i powtarzalności (Karmańska 2006, s. 796-797).

ABC jest podstawą do wdrażania w przedsiębiorstwie zarządzania kosztami działań (ang. activity-based management, ABM). Zarządzanie kosztami działań polega na analizie procesów biznesowych, dekompozycji tych procesów na działania i ich ocenie na podstawie wybranych mierników efektywności. Prowadzi do decyzji związanych przede wszystkim z optymalizacją procesów oraz zużycia zasobów, takich jak redukcja działań nieprzynoszących wartości (i związanych z nim kosztów) czy kontrola niewykorzystanych zdolności produkcyjnych (Fetzer, Kren 2012, s. 6-11). Do ustalenia tych wielkości konieczna jest analiza kosztów zasobów przedsiębiorstwa i ich odpowiednia alokacja do kosztów działań, a także oszacowanie potencjału realizacji działań.

Relacje rachunku kosztów działań i zarządzania kosztami działań prezentuje model tak zwanego krzyża CAM-I, opracowany przez Consortium of Advanced Manufacturing-International (por. rysunek 1). Zakłada on, że kalkulacja kosztów obiektów finalnych jest jednym z dwóch najistotniejszych powodów wdrażania rachunku kosztów działań. Drugim jest optymalizacja procesów. Każde ramię krzyża oznacza inną perspektywę gromadzenia informacji. Odpowiedź na pytanie o koszty obiektów wspiera takie procesy decyzyjne, jak analizy rentowności, kształtowanie portfela produktów i klientów. Informacje o przyczynach powstawania kosztów są istotne przy reengineringu procesów czy identyfikacji obszarów nieefektywności, a także benchmarkingu. Kompleksowa poprawa procesu podejmowania wszystkich decyzji zarządczych występuje w sytuacji, gdy wdrożone rozwiązanie umożliwia oba kierunki przetwarzania informacji. Większość publikacji zakłada wdrażanie przez przedsiębiorstwo modelu w kształcie, który 
umożliwia realizację zadań prezentowanych przez oba ramiona krzyża (np. Adkins, Misch 2015, s. 33-40; Cengiz, Ersoy 2017, s. 183-206; Jelsy, Vetrivel 2012, s. 41-57).

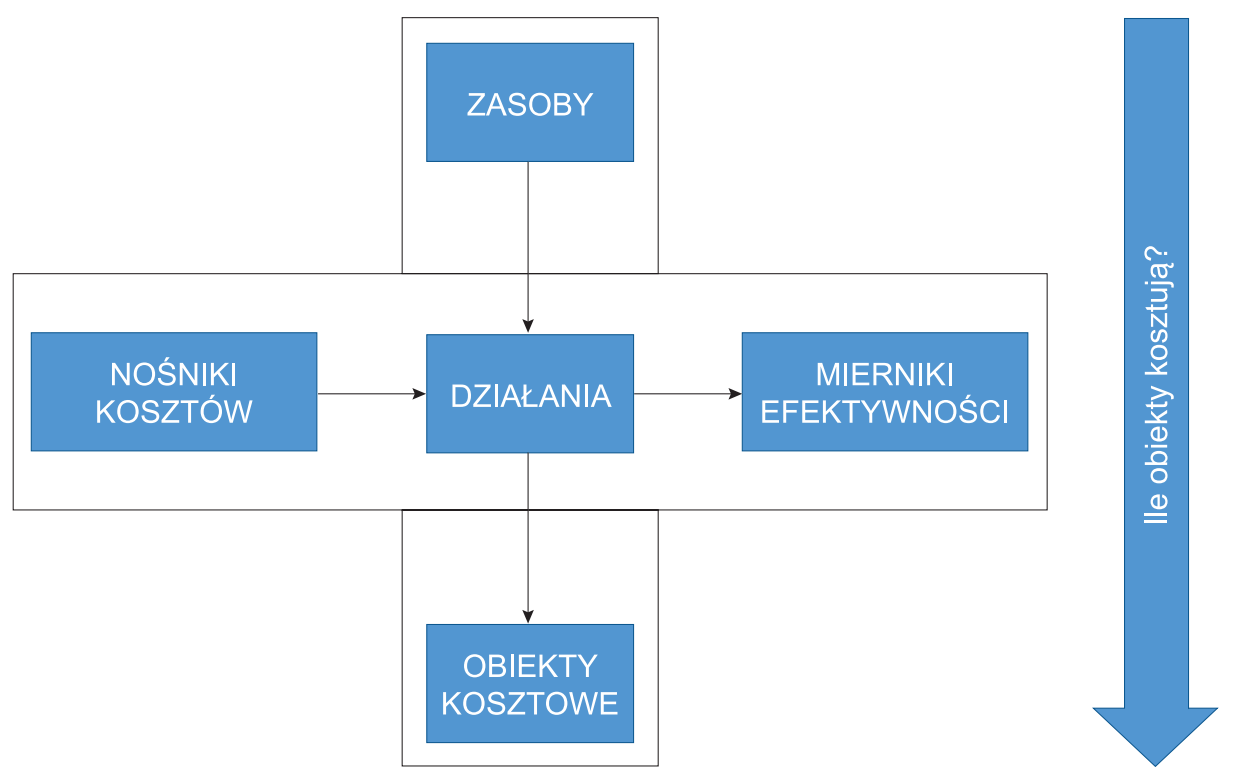

Rysunek 1. „Krzyż CAM-I”

Źródło: Cokins 1999, s. 79; za: Świderska 2010, s. 287.

Wskazywane w literaturze ograniczenia odnośnie do wdrożenia modeli ABC i TD ABC dotyczą przede wszystkim czasochłonności i pracochłonności przy alokacji kosztów działań do obiektów finalnych (Namazi 2016, s. 457-482; Barros, Ferreira 2017, s. 2-20; Hoozée et al. 2012, s. 439-472; Gervais et al. 2010, s. 1-20; Nassar et al. 2013, s. 18-36). Początkowy nakład pracy w przedsiębiorstwach wdrażających $\mathrm{ABC}$ oraz $\mathrm{TD} \mathrm{ABC}$ jest wysoki z uwagi na konieczność oszacowania czasu realizacji poszczególnych działań na rzecz każdego produktu i klienta. Założenie to dotyczy przede wszystkim przedsiębiorstw nieposiadających doświadczenia z analizą swojego portfela produktów i/lub klientów z perspektywy zapotrzebowania na poszczególne działania.

Zarzut praco- i czasochłonności modelu odnosi się przede wszystkim do pionowego ramienia krzyża i alokacji kosztów działań na obiekty finalne. Jednocześnie pozyskanie informacji o działaniach stanowi wystarczające źródło informacji do wdrożenia koncepcji ABM. Uwzględniając powyższe, postanowiono przeprowadzić badanie polegające na rozdzieleniu procesu wdrożenia na dwa etapy, 
dostarczając $w$ pierwszym etapie informacji na temat mierników efektywności wybranych procesów, która miała być wymierną informacją wspierającą zarządzających w ich pracy, prowadzącą docelowo do wzrostu wsparcia zarządzających w zakresie prac nad drugim etapem wdrożenia.

\section{Metodyka badań — organizacja procesu wdrożenia}

Celem badania była weryfikacja, czy wdrożenie rachunku kosztów działań w kształcie umożliwiającym kalkulację kosztów działań i określenie na tej podstawie mierników efektywności pozwoli na otrzymanie wskazywanego w literaturze zakresu informacji użytecznych dla zarządzających przy zaangażowaniu znacznie niższych zasobów, niż wymagałoby tego pełne wdrożenie.

$\mathrm{W}$ toku prac badawczych wskazano obszary, w których wdrożona będzie koncepcja TD ABC. Z uwagi na duże zróżnicowanie procesów produkcyjnych oraz fakt, że są one specyficzne dla grupy przedsiębiorstw produkcyjnych, skoncentrowano się na procesach związanych z obsługą surowców, magazynowaniem, transportem, sprzedażą, marketingiem i ogólnym zarządem. W ramach każdego procesu zdefiniowano działania, jakie mogą w nim wystąpić, oraz zasoby odpowiedzialne za ich realizację.

W początkowej fazie badania punktem wyjścia była indywidualna struktura organizacyjna, analizowana szczegółowo dla każdego $\mathrm{z}$ badanych przedsiębiorstw odrębnie. Następnym etapem była analiza poszczególnych, powtarzalnych grup stanowisk w podziale na wykonywane czynności. Na tym etapie przedsiębiorstwo podawało informacje, stosując własną nomenklaturę zasobów i działań, którą badacze przekładali na działania zdefiniowane w modelu referencyjnym. W praktyce sprowadzało się to niejako do thumaczenia struktury przedsiębiorstwa na słownik badacza. Tą metodyką przebadano około $25 \%$ przedsiębiorstw i na podstawie otrzymanych wyników i doświadczeń opracowano zunifikowaną matrycę ankiety.

Stworzono również wzorcowy szablon ankiety pozwalającej na przyporządkowanie zasobów przedsiębiorstwa do poszczególnych działań, a także na zgromadzenie informacji o kosztach tych zasobów (por. tabele 1 i 2). Aby uniknąć nieścisłości i rozbieżności w stosowanej przez poszczególne podmioty nomenklaturze, zastosowano zamkniętą listę działań, rozbudowaną na tyle, by można było ją dopasować do wszystkich, faktycznie wykonywanych w przedsiębiorstwie działań. Ustandaryzowano także nazwy zasobów, przyjmując stosunkowo szeroką listę, dzięki której możliwe było przyporządkowanie wszystkich wyodrębnionych w przedsiębiorstwach stanowisk. Na tym etapie badania wszelkie wątpliwości były na bieżąco omawiane z przedstawicielami badanych firm i członkami zespołu badawczego. 
Tabela 1. Matryca unifikująca strukturę organizacyjną badanych przedsiębiorstw

\begin{tabular}{|c|c|}
\hline $\begin{array}{c}\text { Komórka wg struktury organizacyjnej } \\
\text { badanej firmy }\end{array}$ & $\begin{array}{l}\text { Zakres czynności wykonywanych } \\
\text { przez pracowników }\end{array}$ \\
\hline Pracownicy bezpośrednio produkcyjni & Produkcja \\
\hline Pracownicy pośrednio produkcyjni & Wsparcie produkcji (pracownicy pośrednio produkcyjni) \\
\hline \multirow{5}{*}{ Magazynierzy } & $\begin{array}{l}\text { Magazynowanie surowców i towarów (w tym przyjęcie } \\
\text { z zewnątrz i wydanie do produkcji) }\end{array}$ \\
\hline & $\begin{array}{l}\text { Przyjęcie wyrobów gotowych z produkcji oraz towarów } \\
\text { do dystrybucji }\end{array}$ \\
\hline & Kompletowanie wysyłki zamówień do klientów \\
\hline & $\begin{array}{l}\text { Przesunięcia w magazynie, np. ze strefy przyjęć do stre- } \\
\text { fy składowania, przesunięcia ramach tej samej strefy np. } \\
\text { w celu poprawy efektywności kompletacji }\end{array}$ \\
\hline & Wysyłka zamówień do klientów \\
\hline Zaopatrzenie & Zamawianie surowców i towarów \\
\hline \multirow{4}{*}{ Transport (kierowcy) } & Planowanie transportu od dostawcy \\
\hline & Transportowanie od dostawcy \\
\hline & Planowanie transportu do klienta \\
\hline & Transportowanie do klienta \\
\hline \multirow{5}{*}{ Dział Handlowy } & Ogólne zarządzanie \\
\hline & $\begin{array}{l}\text { Bieżące działania przedstawicieli handlowych związane } \\
\text { z utrzymaniem klienta bezpośrednio nie związane z po- } \\
\text { zyskaniem zamówienia }\end{array}$ \\
\hline & $\begin{array}{l}\text { Działania handlowe mające na celu podpisanie zamó- } \\
\text { wień przez handlowca }\end{array}$ \\
\hline & $\begin{array}{l}\text { Wystawianie faktur sprzedażowych, faktur korygują- } \\
\text { cych, uzgodnienia z klientami dotyczące rozliczeń }\end{array}$ \\
\hline & Działania mające na celu pozyskiwanie nowych klientów \\
\hline \multirow{2}{*}{ Dział Marketingu } & $\begin{array}{l}\text { Działania marketingowe bez ukierunkowania na kon- } \\
\text { kretnego klienta i/lub produkt }\end{array}$ \\
\hline & $\begin{array}{l}\text { Działania marketingowe związane bezpośrednio z pro- } \\
\text { mocją produktu }\end{array}$ \\
\hline Dział Kadr & Działania związane z obsługą kadr i płac \\
\hline Dział IT & Działania związane z obsługą IT \\
\hline \multirow{2}{*}{ Dział Księgowości i Finansów } & Księgowania dokumentów i analizy finansowe \\
\hline & Działania związane z obsługą kadr i płac \\
\hline Dział Administracji, Ogólny Zarząd & Ogólne zarządzanie \\
\hline
\end{tabular}

Źródło: opracowanie FiM Consulting. 
Tabela 2. Matryca przekładająca strukturę organizacyjną badanych przedsiębiorstw na zasoby modelu referencyjnego

\begin{tabular}{|c|c|c|}
\hline Zakres czynności wykonywanych przez pracowników & & $\begin{array}{l}\text { Zasób wg modelu } \\
\text { referencyjnego }\end{array}$ \\
\hline $\begin{array}{l}\text { Magazynowanie surowców i towarów (w tym przyjęcie } \\
\text { z zewnątrz i wydanie do produkcji) }\end{array}$ & \multirow{5}{*}{$\sqrt{2}$} & Zespół magazynu indeksów \\
\hline $\begin{array}{l}\text { Przyjęcie wyrobów gotowych z produkcji oraz towa- } \\
\text { rów do dystrybucji }\end{array}$ & & Zespół magazynu indeksów \\
\hline Kompletowanie wysyłki zamówień do klientów & & Zespół magazynu indeksów \\
\hline $\begin{array}{l}\text { Przesunięcia w magazynie, np. ze strefy przyjęć do stre- } \\
\text { fy składowania, przesunięcia w ramach tej samej strefy } \\
\text { np. w celu poprawy efektywności kompletacji }\end{array}$ & & Zespół magazynu indeksów \\
\hline Wysyłka zamówień do klientów & & Zespół magazynu indeksów \\
\hline Zamawianie surowców i towarów & & Zespół zaopatrzenia \\
\hline Planowanie transportu od dostawcy & \multirow{4}{*}{ 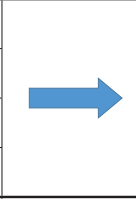 } & Transport własny logistyki \\
\hline Transportowanie od dostawcy & & Transport własny logistyki \\
\hline Planowanie transportu do klienta & & Transport własny logistyki \\
\hline Transportowanie do klienta & & Transport własny logistyki \\
\hline $\begin{array}{l}\text { Bieżące działania przedstawicieli handlowych związa- } \\
\text { ne z utrzymaniem klienta bezpośrednio nie związane } \\
\text { z pozyskaniem zamówienia }\end{array}$ & \multirow{4}{*}{$\vec{\square}$} & Zespół handlowy \\
\hline $\begin{array}{l}\text { Działania handlowe mające na celu podpisanie zamó- } \\
\text { wień przez handlowca }\end{array}$ & & Zespół handlowy \\
\hline $\begin{array}{l}\text { Wystawianie faktur sprzedażowych, faktur korygują- } \\
\text { cych, uzgodnienia z klientami dotyczące rozliczeń }\end{array}$ & & Zespół handlowy \\
\hline $\begin{array}{l}\text { Działania mające na celu pozyskiwanie nowych klien- } \\
\text { tów }\end{array}$ & & Zespół handlowy \\
\hline $\begin{array}{l}\text { Działania marketingowe bez ukierunkowania na kon- } \\
\text { kretnego klienta i/lub produkt }\end{array}$ & \multirow{2}{*}{$\vec{r}$} & Marketing ogólny \\
\hline $\begin{array}{l}\text { Działania marketingowe związane bezpośrednio z pro- } \\
\text { mocją produktu }\end{array}$ & & Marketing ogólny \\
\hline Działania związane z obsługą kadr i płac & & Dział Kadr \\
\hline Działania związane z obsługą IT & & IT \\
\hline Księgowania dokumentów i analizy finansowe & \multirow{2}{*}{$\Rightarrow$} & Księgowość \\
\hline Działania związane z obsługą kadr i płac & & Księgowość \\
\hline Ogólne zarządzanie & & $\begin{array}{l}\text { Administracja/ Koszty } \\
\text { Ogólnego Zarządu }\end{array}$ \\
\hline
\end{tabular}

Źródło: opracowanie FiM Consulting. 
Zakres informacji dostarczanych przez poszczególne przedsiębiorstwa obejmował informacje o:

1. liczbie etatów w poszczególnych komórkach organizacyjnych w podziale na zespoły realizujące jednorodne działania;

2. procentowym zaangażowaniu pracowników danych zespołów w realizację czynności zdefiniowanych przez zespół wdrożeniowy w wyniku wywiadów z firmami zbadanymi w pierwszym etapie analizy;

3. kosztach wyodrębnionych zespołów w podziale na koszty osobowe i nieosobowe (por. tabela 3).

Tabela 3. Matryca do zbierania danych o kosztach poszczególnych zespołów

\begin{tabular}{|c|c|c|c|}
\hline $\begin{array}{c}\text { Komórka / Grupa } \\
\text { kosztów }\end{array}$ & Zasób & $\begin{array}{c}\text { KOSZTY } \\
\text { OSOBOWE } \\
\text { (koszty wynagrodzeń, } \\
\text { narzutów na wynagro- } \\
\text { dzenia oraz pozostałe } \\
\text { koszty pracownicze } \\
\text { typu badania lekarskie, } \\
\text { odzież robocza, fundusz } \\
\text { świadczeń socjalnych) }\end{array}$ & $\begin{array}{c}\text { KOSZTY } \\
\text { NIEOSOBOWE } \\
\text { (zużycie materiałów, } \\
\text { usługi obce, środki } \\
\text { trwałe i niskocenne, } \\
\text { koszty delegacji, } \\
\text { amortyzacja, podatki } \\
\text { i opłaty, leasingi, ubez- } \\
\text { pieczenia pozostałe) }\end{array}$ \\
\hline $\begin{array}{l}\text { Pracownicy bezpo- } \\
\text { średnio produkcyjni / } \\
\text { Koszty bezpośrednie }\end{array}$ & $\begin{array}{l}\text { Koszty pomocnicze } \\
\text { produkcji }\end{array}$ & & \\
\hline $\begin{array}{l}\text { Pracownicy pośrednio } \\
\text { produkcyjni / Koszty } \\
\text { pośrednie do produkcji }\end{array}$ & $\begin{array}{l}\text { Koszty pomocnicze } \\
\text { produkcji }\end{array}$ & & \\
\hline Magazynierzy & $\begin{array}{l}\text { Zespół magazynu } \\
\text { indeksów }\end{array}$ & & \\
\hline Zaopatrzenie & $\begin{array}{l}\text { Zespół zaopatrze- } \\
\text { nia }\end{array}$ & & \\
\hline Transport (kierowcy) & $\begin{array}{l}\text { Transport własny } \\
\text { logistyki }\end{array}$ & & \\
\hline Dział Handlowy & Zespół handlowy & & \\
\hline $\begin{array}{l}\text { Dział Marketingu } \\
\text { (w tym koszty rekla- } \\
\text { my) }\end{array}$ & Marketing ogólny & & \\
\hline Dział Kadr & Dział Kadr & & \\
\hline Dział IT & IT & & \\
\hline $\begin{array}{l}\text { Dział Księgowości } \\
\text { i Finansów }\end{array}$ & Księgowość & & \\
\hline $\begin{array}{l}\text { Administracja (w tym } \\
\text { również koszty arty- } \\
\text { kułów spożywczych) }\end{array}$ & Administracja & & \\
\hline
\end{tabular}




\begin{tabular}{l|l|l|l}
\hline Ogólny Zarząd & $\begin{array}{l}\text { Koszty Ogólnego } \\
\text { Zarządu }\end{array}$ & \\
\hline $\begin{array}{l}\text { Spedycja, kurier, } \\
\text { poczta - dotyczące } \\
\text { wysyłki towarów do } \\
\text { klientów }\end{array}$ & Spedycja & ND & \\
\hline $\begin{array}{l}\text { Spedycja, kurier, } \\
\text { poczta - koszty do- } \\
\text { tyczące dostarczenia } \\
\text { surowców }\end{array}$ & Spedycja & ND & \\
\hline $\begin{array}{l}\text { Wsparcie marketin- } \\
\text { gowe klientów (tzw. } \\
\text { usługi marketingowe) }\end{array}$ & Wusparcie pozabo- & ND & \\
\hline $\begin{array}{l}\text { Wartość sprzedanych } \\
\text { towarów i materiałów }\end{array}$ & $\begin{array}{l}\text { Wartość sprzeda- } \\
\text { nych indeksów }\end{array}$ & ND & \\
\hline
\end{tabular}

Źródło: opracowanie FiM Consulting.

Na podstawie zgromadzonych danych i wywiadów z pracownikami przedsiębiorstwa zespół badawczy mapował dane przedsiębiorstwa do słownika zasobów, działań i procesów. Otrzymane informacje pozwalały na ustalenie łącznych kosztów poszczególnych działań i procesów. Powiązanie tych informacji z przychodami pozwalało na stworzenie rachunku marżowego dla przedsiębiorstwa opartego na podejściu procesowym.

Kolejnym etapem było ustalenie mierników efektywności procesów, w tym mierników umożliwiających oszacowanie poziomu kosztów niewykorzystanego potencjału. Koszt niewykorzystanego potencjału oszacowano w sposób uproszczony dla wybranych działań - w ramach procesu sprzedaży związanych z pozyskiwaniem zamówień oraz $\mathrm{w}$ ramach procesów magazynowych związanych z kompletowaniem zamówień i przygotowaniem ich do wysyłki. Za miernik efektywności działań przyjęto liczbę wystawionych faktur sprzedażowych i korekt faktur sprzedaży. W sytuacji odchylenia poziomu tych dokumentów od poziomu maksymalnego identyfikowano występowanie niewykorzystanego potencjału. Mając na uwadze bardzo duży stopień uproszczenia, wskaźniki te interpretowane były jako pokazanie tendencji i uświadomienie istnienia i skali problemu niewykorzystanego potencjału.

Zdefiniowano około 100 różnych wskaźników mierzenia efektywności działań, które pogrupowano w następujące kategorie:

1. rentowności - mierzące udział marż różnego poziomu w przychodzie;

2. struktury kosztów - mierzące udział kosztów działań w kosztach procesów, kosztów procesów w kosztach łącznych czy kosztów zasobów w działaniach;

3. kosztochłonności zasobów ludzkich - mierzące koszt jednostkowy zasobów ludzkich zaangażowane w procesy;

4. efektywności - mierzące wydajność wybranych działań lub zasobów. 


\section{Rezultaty empiryczne}

Wdrożenie zainicjowano w 60 przedsiębiorstwach działających w Polsce, wybranych w sposób celowy pod warunkiem spełniania przez nie następujących kryteriów wejściowych:

1. realizacja przynajmniej $75 \%$ działań zdefiniowanych w modelu;

2. roczne obroty na poziomie co najmniej $5 \mathrm{mln}$ zł;

3. zatrudnienie na poziomie co najmniej 20 osób, przy czym do zatrudnienia wliczono stałych pracowników i współpracowników zatrudnionych na umowę zlecenie, umowę o dzieło lub umowę cywilnoprawną.

Wdrożenia realizowano w latach 2013-2015 przy zaangażowaniu personelu badanych przedsiębiorstw oraz członków zespołu badawczego, posiadających wiedzę na temat opracowanej koncepcji wdrożenia i wdrażanego modelu rachunku kosztów działań sterowanego czasem.

Proces wdrożenia w wypadku pierwszych wdrożeń trwał 14 osobodni pracy badaczy oraz 3-6 osobodni pracy pracowników badanych firm, w zależności od poziomu skomplikowania struktury organizacyjnej. Po przebadaniu około $25 \%$ przedsiębiorstw z założonej próby oraz doprecyzowaniu procedur działania czas został ograniczony do 4 osobodni pracy badaczy i 1-3 dni pracowników badanych firm, w zależności od skomplikowania struktury spółki oraz dokładności ewidencji kosztów.

Wdrożenie zakończono w 44 spośród badanych przedsiębiorstw. Przyczynami niepowodzenia pozostałych przypadków wdrożenia były:

1. subiektywne uznanie przez przedsiębiorstwo, że badanie jest zbyt skomplikowane dla za małej liczby realizowanych procesów - 3 przedsiębiorstwa;

2. zmiany restrukturyzacyjno-właścicielskie -4 przedsiębiorstwa;

3. zbyt długi czas zaangażowania pracowników w przygotowanie danych zasilających do modelu referencyjnego przez pracowników badanych firm 5 przedsiębiorstw;

4. zastosowanie kompleksowego podejścia do TD ABC w oparciu o dane źródłowe z systemów sprzedażowych, magazynowych i finansowo-księgowych -4 przedsiębiorstwa.

Wdrożono model umożliwiający sporządzenie rachunku marżowego z uwzględnieniem kosztów wybranych procesów, lecz także wyodrębnienie szacunkowych kosztów niewykorzystanego potencjału we wskazanych obszarach i zestaw mierników efektywności procesów.

Pierwszym efektem wdrożenia dla zarządzających był rachunek zysków i strat, w którym przychody ze sprzedaży zostały zestawione z kosztami przedstawionymi w układzie działań i dodatkowo pogrupowanymi zgodnie $\mathrm{z}$ hierarchią działań (por. Cokins 1993). Na każdym poziomie hierarchii została wyliczona marża zysku. Uzyskanie tego efektu było możliwe w sytuacji, gdy przedsiębior- 
stwo podało $\mathrm{w}$ ankiecie informacje finansowe na temat przychodów oraz łącznych kosztów ośrodków kosztów w podziale na zasoby wraz ze wskazaniem procentowego udziału poszczególnych zasobów (lub ich grup) w realizacji działań. W rezultacie stworzono schemat rachunku marżowego (zob. tabela 5-6). Z uwagi na jednolite podejście do raportu marżowego wyniki uzyskane w poszczególnych przedsiębiorstwach mogły zostać ze sobą zestawione i przedstawione zwrotnie zarządzającym — po ich statystycznej obróbce — dla celów benchmarkingowych.

Tabela 4. Rachunek marżowy

Rachunek Zysków i Strat dla Produktów

\begin{tabular}{|c|c|c|c|}
\hline Okres & \multicolumn{3}{|l|}{ All } \\
\hline Zakres & \multicolumn{3}{|l|}{ RMWW } \\
\hline Układ & \multicolumn{3}{|l|}{ Produkt-Klient } \\
\hline & \multicolumn{3}{|l|}{ Wartości } \\
\hline Etykiety wierszy & Koszt RM & Marża & $\mathrm{Mn} / \mathrm{P}$ \\
\hline Przychód & 0 & 8628865 & 1,00 \\
\hline M1-koszty bezpośrednie & 6074895 & 2553970 & 0,30 \\
\hline M2-koszty pośrednie produktu & 115361 & 2438609 & 0,28 \\
\hline M3-koszty obsługi klienta & 1161733 & 1276876 & 0,15 \\
\hline M4-obsługa klientów potencjalnych & 253141 & 1023735 & 0,12 \\
\hline M5-koszty ogólnozakładowe & 712573 & 311162 & 0,04 \\
\hline M6-koszty niewykorzystane & 222648 & 88514 & 0,01 \\
\hline
\end{tabular}

Źródło: dane przykładowe - opracowanie FiM Consulting.

Tabela 5. Rachunek marżowy ze szczegółową prezentacją kosztów obsługi klienta

Rachunek Zysków i Strat dla Produktów

\begin{tabular}{|c|c|c|c|}
\hline Okres & \multicolumn{3}{|l|}{ All } \\
\hline Zakres & \multicolumn{3}{|l|}{ RMWW } \\
\hline Układ & \multicolumn{3}{|l|}{ Produkt-Klient } \\
\hline & \multicolumn{3}{|l|}{ Wartości } \\
\hline Etykiety wierszy & Koszt RM & Marża & $\mathrm{Mn} / \mathrm{P}$ \\
\hline Przychód & 0 & 8628865 & 1,00 \\
\hline M1-koszty bezpośrednie & 6074895 & 2553970 & 0,30 \\
\hline M2-koszty pośrednie produktu & 115361 & 2438609 & 0,28 \\
\hline M3-koszty obsługi klienta & 1161733 & 1276876 & 0,15 \\
\hline
\end{tabular}

Kompletacja dostaw

Zespół Magazynu Indeksów

23590

Ekonomia - Wroclaw Economic Review 23/3 (2017)

(C) for this edition by CNS 
Obstuga sprzedaży

Księgowość i Finanse

101712

Planowanie transportu do klienta

Zespół Transportu

Pozyskiwanie zamówień

Zespół Handlowy

Transportowanie do klienta

Spedycja

530996

Zespół Transportu

Utrzymanie relacji z klientami

Koszty Ogólnego Zarządu

Zespół Handlowy

Wsparcie pozabonusowe klientów

Wsparcie Pozabonusowe Klientów

Wysytka indeksów

Zespół Magazynu Indeksów

94409

\begin{tabular}{lrrr}
\hline WYNIK PO MARŻY 3 & 1276876 & 0,15 \\
\hline M4-obsługa klientów potencjalnych & 253141 & 1023735 & 0,12 \\
\hline M5-koszty ogólnozakładowe & 712573 & 311162 & 0,04 \\
\hline M6-koszty niewykorzystane & 222648 & 88514 & 0,01 \\
\hline
\end{tabular}

Źródło: dane przykładowe - opracowanie FiM Consulting.

Drugim celem było określenie kosztów niewykorzystanego potencjału dla wybranych procesów. Dane niezbędne dla określenia tego wskaźnika - poza informacjami o kosztach poszczególnych procesów, które były niezbędne już na etapie określania rachunku marżowego - obejmowały również dane niefinansowe, dotyczące liczby jednostek wybranych nośników kosztów - wystawionych faktur sprzedażowych i korekt faktur sprzedaży (tabela 6).

Tabela 6. Matryca do zbierania danych o operacjach sprzedażowych

\begin{tabular}{c|c|c}
\hline Miesiąc & $\begin{array}{c}\text { Liczba pozycji na fakturach } \\
\text { sprzedaży }\end{array}$ & $\begin{array}{c}\text { Liczba pozycji na fakturach } \\
\text { korygujących }\end{array}$ \\
\hline I-13 & 2550 & 41 \\
\hline II-13 & 2224 & 58 \\
\hline III-13 & 2870 & 51 \\
\hline IV-13 & 2714 & 64 \\
\hline V-13 & 2982 & 90 \\
\hline VI-13 & 2598 & 70 \\
\hline VII-13 & 2988 & 51 \\
\hline VIII-13 & 2772 & 78 \\
\hline
\end{tabular}




\begin{tabular}{c|c|c}
\hline IX-13 & 2916 & 71 \\
\hline X-13 & 3072 & 69 \\
\hline XI-13 & 2580 & 39 \\
\hline XII-13 & 2704 & 53 \\
\hline Razem & 32970 & 735 \\
\hline
\end{tabular}

Źródło: dane przykładowe - opracowanie FiM Consulting.

Dane zgromadzono dla 44 podmiotów, przy czym w przypadku 13 z nich badanie nie wykazało problemu niewykorzystanego potencjału i braku rozbieżności między miesięcznymi danymi o liczbie dokumentów księgowych, co może świadczyć o uproszczonym sposobie wypełnienia ankiety przez przedsiębiorstwo i podaniu danych rocznych podzielonych równomiernie na poszczególne miesiące. Dla 31 podmiotów oszacowano koszty niewykorzystanego potencjału.

Trzecim efektem wdrożenia było obliczenie poszczególnych mierników efektywności procesów. $Z$ uwagi na to, że ustalone mierniki bazowały na informacjach niezbędnych dla określenia rachunku marżowego — kosztach zasobów, ilości zasobów ludzkich w poszczególnych zespołach oraz ich procentowym zaangażowaniu na rzecz poszczególnych działań - osiągnięte rezultaty wdrożenia były identyczne jak w przypadku rachunku marżowego, wyniki uzyskano dla 44 przedsiębiorstw.

\section{Wnioski}

Przeprowadzone badanie wykazało możliwość realizacji pierwszego etapu wdrożenia rachunku kosztów działań sterowanego czasem w ciągu 4 osobodni w sposób umożliwiający uzyskanie trzech efektów dla zarządzających:

1. sporządzenie rachunku marżowego z uwzględnieniem kosztów procesów;

2. określenie kosztu niewykorzystanych zasobów;

3. kalkulacja zdefiniowanych mierników oceny procesów mierzących ich rentowność, efektywność, strukturę kosztów oraz koszt utrzymywania zasobów ludzkich.

Cel ten zrealizowano łącznie u ponad $70 \%$ podmiotów, co znacznie przekracza rezultaty wdrożenia modelu $\mathrm{ABC}$ przedstawione dotychczas. Warto jednak zaznaczyć, że osiągnięty rezultat dotyczy pierwszego etapu modelu dwuetapowego. Dalsze badania w analizowanych przedsiębiorstwach pozwolą stwierdzić, czy korzyści z otrzymanych informacji w układzie działań i procesów stanowią istotny czynnik zachęcający zarządzających do wdrożenia rachunku kosztów działań w jego pełnym kształcie. Warto zaznaczyć, że w trakcie badania 4 przedsiębiorstwa, w których wdrożono pierwszy etap TD ABC, zachęcone uzyskanymi wynikami, zdecydowały się na wdrożenie pełnego modelu. 
Już po pierwszym etapie wdrożenia rysują się wnioski, które będą miały wpływ na sukces implementacji. Jak już wspomniano, wdrożenie w niektórych przedsiębiorstwach nie powiodło się z uwagi na kilka głównych przesłanek, takich jak:

1. nieświadomość złożoności procesów realizowanych w firmie;

2. subiektywna ocena badanego podmiotu o nieadekwatności zaangażowania pracy własnej kadry w stosunku do oczekiwanych rezultatów;

3. zmiany restrukturyzacyjno-właścicielskie.

Zdecydowanie niższy odsetek podmiotów raportujących informacje niefinansowe, pozwalające na oszacowanie niewykorzystanego potencjału ( $70 \%$ spośród podmiotów, w których zrealizowano wdrożenie), wskazują na brak skłonności przedsiębiorstw do akceptacji faktu, że może występować w nich problem niewykorzystanego potencjału. Czynnik ten może utrudniać wdrożenie TD ABC, którego jedną z immanentnych cech jest identyfikacja właśnie tego problemu. Możliwym działaniem jest poprawa świadomości zarządzających w zakresie roli informacji o niewykorzystanym potencjale w zarządzaniu przedsiębiorstwem, na przykład poprzez publikacje branżowe i szkolenia.

\section{Bibliografia}

Adkins T., Misch B. (2015), Does it always make sense to share? Costing in a shared services environment, „Cost Management” marzec/kwiecień, s. 33-40.

Barros R., Ferreira A. (2017), Time-driven activity-based costing: Designing a model in a Portuguese production environment, „Qualitative Research in Accounting and Management” 14(1), s. $2-20$.

Cengiz E., Ersoy A. (2017), Decision On Cost Reduction: A Holistic View, Muhasebe ve Finansman Dergisi, s. 183-206.

Cooper R. (1990), Cost classification in unit-based and activity-based manufacturing cost systems, „Journal of Cost Management”.

Cooper R., Kaplan R.S. (1988), How cost accounting systematically distorts product costs, „Management Accounting", kwiecień, s. 20-27.

Cotton W., Jackman S., Brown R. (2003), Note on a New Zealand replication of the Innes et al. UK activity-based costing survey, „Management Accounting Research” 14, s. 67-72.

Fetzer B., Kren L. (2012), More Effective Planning in a Traditional Two-Stage Cost System with Activity-Based Management (ABM), „Cost Management” 26 (6), s. 6-11.

Gervais M., Levant Y., Ducrocq C. (2010), Time-driven activity-based costing (TDABC): An initial appraisal through a longitudinal case study, „Journal of Applied Management Accounting Research" 8 (2), s. 1-20.

Hoozée S., Bruggeman W. (2012), Identifying operational improvements during the design process of a time-driven ABC system: the role of collective worker participation and leadership style, „Management Accounting Research” 21 (3), s. 185-198.

Innes J., Mitchell F. (1995), A survey of activity-based costing in the U.K.'s largest companies, „Management Accounting Research” 6, s. 137-153.

Innes J., Mitchell F., Sinclair D. (2000), Activity-based costing in the U.K. 's largest companies: a comparison of 1994 and 1999 survey results, „Management Accounting Research” 11, s. 349-362. 
Jelsy J., Vetrivel A. (2012), Impact of target cvosting and activity based costing on omproving the profitability of Spinning Mills in Coimbatore - Empirical study on Spinning Mills, „Journal of Contemporary Research in Management" 7(2), s. 41-57.

Kaplan R.S., Anderson S.R. (2008), Rachunek kosztów dziatań sterowany czasem. Prostsza i bardziej skuteczna droga do większych zysków, Warszawa.

Kaplan R.S., Cooper R. (1998), Cost and Effect: Using Integrated Systems to Drive Profitability and Performance, Boston.

Karmańska A. (red.) (2006), Rachunkowość zarządcza i rachunek kosztów w systemie informacyjnym przedsiębiorstwa, Warszawa.

McGowan A.S. (1998), Perceived benefits of ABCM implementation, „Accounting Horizons” 1, s. 31-50.

McGowan A.S., Klammer T.P. (1997), Satisfaction with activity-based cost management implementation, „Journal of Management Accounting Research” 9, s. 217-237.

Nassar M. et al. (2013), Factors that catalyse, facilitate and motivate the decision to implement activity-based costing in Jordanian industrial companies, „Journal of Applied Accounting Research" 14 (1), s. 18-36.

Nowak E. (red.) (2004), Rachunek kosztów w zarządzaniu przedsiębiorstwem, Warszawa.

Rybarczyk K. (1998), Zastosowanie rachunku kosztów działań do kalkulacji i analizy kosztów obstugi klienta, „Zeszyty Teoretyczne Rady Naukowej SKwP” 46, s. 151-162.

Rybarczyk K. (2000), Rachunek kosztów działań. Uwagi o potrzebie i możliwościach zastosowania w praktyce, [w:] Budżetowanie działalności jednostek gospodarczych — teoria i praktyka, red. W. Krawczyk, materiały konferencyjne, Kraków.

Shields M. (1995), An empirical analysis of firms' implementation experiences with activity-based costing, ,Journal of Management Accounting Research” 7, s. 148-166.

Świderska G.K. (red.) (2010), Controlling kosztów i rachunkowość zarządcza, Warszawa.

Świderska G.K., Warowny P. (2007), Wplyw stosowanej metody wdrożenia rachunku kosztów dziatań na zakres uzyskiwanych informacji, „Controlling i Rachunkowość Zarządcza” 2.

Wnuk-Pel T. (2011), Zastosowanie rachunku kosztów działań w przedsiębiorstwach w Polsce, Łódź. 